\title{
Premature Rupture of Membranes and Effects of Prophylactic Antibiotics
}

\author{
ALEX H. HABEL, GEORGE S. SANDOR, NANCY K. CONN, and W. MORRICE MCCRAE \\ From the Department of Child Life and Health, University of Edinburgh; and the Central Microbiological Laboratories, \\ Western General Hospital, Edinburgh
}

\begin{abstract}
Habel, A. H., Sandor, G. S., Conn, N. K., and McCrae, W. M. (1972). Archives of Disease in Childhood, 47, 401. Premature rupture of membranes and effects of prophylactic antibiotics. A series of 100 infants born after prolonged rupture of membranes was studied to evaluate the risk of infection to the infant due to this circumstance alone, and to assess the effect of prophylactic antibiotics in its prevention. Evidence of bacterial colonization at birth was limited to 6 cases and no clinical infection ensued. Neonatal infection was uniformly low but the administration of antibiotics led to clinical candidiasis in $18 \%$ and the development of a replacement flora of fungi in the intestinal tract in $70 \%$. It is concluded that the routine administration of prophylactic antibiotics to the infant born in these circumstances is unnecessary and potentially hazardous.
\end{abstract}

It is commonly supposed that premature rupture of the membranes followed by a long interval before delivery increases the risk of neonatal infection, particularly 'congenital pneumonia' (Blanc, 1961; Pryles et al., 1963). Recognizing such a risk and in an attempt to counter it many paediatricians give prophylactic antibiotics routinely to the neonate when delivery has been delayed for more than 24 hours after membrane rupture (Bound, Butler, and Spector, 1956; Anderson et al., 1962). However, this policy may be mistaken. The degree of risk to the infant from premature rupture of the membranes, in the absence of other obstetric difficulties, has never been satisfactorily assessed, and even if it were established, there is no clear evidence from controlled trials that prophylactic antibiotics are useful in this situation (Petersdorf et al., 1957). Indeed the overall result of the routine use of prophylactic antibiotics may be an increased incidence of infection, particularly due to antibiotic resistant organisms (Price and Sleigh, 1970).

The following study was designed to review the place of prophylactic antibiotics in the management of the neonate after premature rupture of the membranes.

\section{Material and Methods}

The study was carried out at the Elsie Inglis Memorial Hospital where there are approximately 2100 deliveries

Received 20 October 1971. each year. During the period January to September 1970,100 infants were born 24 hours or more after the initial rupture of the membranes and all of these cases were included to form the study series.

After each of the study cases, the next infant to be born in the hospital but delivered within 24 hours of membrane rupture was observed as a control.

Among the study cases were a number who might be considered to be at particular risk of neonatal infection for reasons other than uncomplicated rupture of the membranes. For the purposes of this study, the following factors were considered to create such a risk.

(1) Maternal factors-amnionitis (indicated by foul smelling liquor, purulent discharge, or pyrexia greater than $\left.37.5^{\circ} \mathrm{C}\right)$.

(2) Obstetric complications-caesarian section, Ventouse or forceps delivery, prolapsed cord, fetal distress.

(3) Paediatric complications (intra- or post-partum)endotracheal intubation, low Apgar at 5 minutes, umbilical catheterization, subdural taps, clinical evidence of infection.

These complicating factors were recognized in 38 of the 100 study cases and prophylactic antibiotics were given as described below. Each alternate case of the remaining 62 patients in the study group was also given prophylactic antibiotic treatment. The 100 control patients did not receive antibiotics. The 200 infants on whom observations were made during the trial were therefore allotted to one of 4 groups as follows.

Group $A$-infants delivered 24 hours or more after rupture of the membranes but given no antibiotics.

Group $B$-infants delivered 24 hours or more after rupture of the membranes and given prophylactic antibiotics. 
Group $C$-infants delivered 24 hours or more after rupture of the membranes but considered (for reasons described above) to be at particular risk and therefore given prophylactic antibiotics.

Group D-100 control infants thought to be completely well after normal deliveries and given no antibiotics.

The distribution of the cases is given in Table $I$.

TABLE I

Distribution of Cases into 4 Groups (see text)

\begin{tabular}{l|c|c|c|c}
\hline \multicolumn{1}{c|}{ Group } & A & B & C & D \\
\hline Total number & 31 & 31 & 38 & 100 \\
Mean duration of rupture (hr) & $\mathbf{4 8}$ & 35 & 74 & $5 \cdot 5$ \\
Mean duration of labour (hr) & 11 & 11 & $20^{\star}$ & 2 \\
\hline
\end{tabular}

^Excluding 9 patients who did not proceed to vaginal delivery but were delivered by caesarian section.

\section{Clinical Methods}

A similar regimen was maintained for all cases in the 4 groups. At delivery, swabs for bacteriological examination were taken from the eyes, nasopharynx, umbilicus, and fetal surface of the placenta. Gastric aspirate was taken for culture.

On the fourth day of life swabs were again taken from the eyes, nasopharynx, and umbilicus. Specimens of faeces and 'clean-catch' urine were collected for culture. This 'follow-up' group of specimens, however, was lacking in 5 instances-4 infants all belonging to Group C having died, and 1 control infant (Group D) having been removed from hospital before the fourth day.

Initial bathing was carried out at 4 hours, using ordinary soap followed by hexachlorophane dusting. Surgical spirit was used in the care of the umbilicus.

The antibiotics administered were ampicillin and cloxacillin, each in a dosage of $62.5 \mathrm{mg}$ 6-hourly (except in the case of those infants weighing less than $2.5 \mathrm{~kg}$ when the dosage was reduced to $32.5 \mathrm{mg}$ ). Four initial doses were given intramuscularly and treatment was thereafter continued orally for 5 days.

Throughout the period of the study, temperature, pulse rate, and respiration rate were recorded twice daily. Every patient was examined twice daily by one of the authors, paying particular attention to those signs described by Gotoff and Behrman (1970) as supporting a diagnosis of sepsis.

\section{Bacteriology Methods}

The swabs of amnion and umbilicus and the gastric aspirate were inoculated onto blood agar plates and incubated aerobically and anaerobically. Swabs from the nasopharynx and the eyes were inoculated onto blood agar and chocolate agar plates and incubated in $\mathrm{CO}_{2}$. Urine specimens were plated onto MacConkey medium by the technique of Urquhart and Gould (1965) to give both a qualitative and quantitative result. Tests for the presence of antibacterial activity were also carried out by the disc titration method described by
Gould (1965). Faeces specimens were inoculated onto blood agar and MacConkey medium plates. Both were incubated aerobically and a blood agar plate was also incubated anaerobically. All cultures were incubated overnight at $37^{\circ} \mathrm{C}$.

\section{Results}

Bacteriological investigations at birth. The samples taken at birth from 194 infants showed no evidence of significant bacterial 'colonization'. The solid media cultures yielded virtually no growth apart from an occasional colony of Staphylococcus albus, coliform bacillus, or streptococcus.

In the remaining 6 cases the isolation of a single species in pure culture and in considerable numbers from multiple sites indicated that significant surface bacterial colonization had occurred before or during delivery (Table II). It is of interest that one of these cases was in the control series, delivery having been $16 \frac{1}{2}$ hours after membrane rupture. Three of the 6 cases received antibiotics but none of the 6 showed evidence of clinical infection at

TABLE II

Incidence of Bacterial Colonization at Birth

\begin{tabular}{|c|c|c|c|c|}
\hline $\begin{array}{l}\text { No. of } \\
\text { Infants }\end{array}$ & Group & $\begin{array}{c}\text { Interval After } \\
\text { Membrane } \\
\text { Rupture (hr) }\end{array}$ & Organism & Site \\
\hline 135 & A & 40 & $\begin{array}{l}\text { Haemolytic } \\
\text { streptococcus } \\
\text { Group C }\end{array}$ & $\begin{array}{l}\text { Umbilicus; } \\
\text { eyes }\end{array}$ \\
\hline 197 & B & 29 & $\begin{array}{l}\text { Strep. } \\
\text { viridans }\end{array}$ & All sites \\
\hline 176 & B & 39 & $\begin{array}{l}\text { Strep. } \\
\text { viridans }\end{array}$ & All sites \\
\hline 47 & C & $32 \frac{1}{2}$ & $\begin{array}{l}\text { Haemolyptic } \\
\text { streptococcus } \\
\text { Group B }\end{array}$ & All sites \\
\hline 159 & C & 34 & Enterococcus & $\begin{array}{l}\text { All sites } \\
\text { except } \\
\text { umbilicus }\end{array}$ \\
\hline 37 & D & $16 \frac{1}{2}$ & Enterococcus & $\begin{array}{l}\text { All sites } \\
\text { except } \\
\text { eyes }\end{array}$ \\
\hline
\end{tabular}

any time, and in no case did evidence of bacterial colonization persist. The fourth day specimens yielded no growth in 2 of the 3 treated cases and mixed commensal organisms in the remaining 4, the original streptococcus in all instances being absent.

Neonatal infections. The incidence of clinical infection during the trial period was low and in keeping with that normally experienced in this unit. Six incidents of infection were recorded, 3 occurring in the study series and 3 in the control series. All were considered to be minor in nature 
and 5 consisted of purulent conjunctivitis, while the sixth (belonging to Group D) was a case of omphalitis. Staphylococcus albus was isolated from all 6 lesions (Table III).

TABLE III

Incidence of Neonatal Infection

\begin{tabular}{l|r|r|r|r}
\hline \multicolumn{1}{c|}{ Group } & & & & \\
& A & B & C & D \\
\hline No. of infants & 31 & 31 & 38 & 100 \\
Minor bacterial infections & 2 & 0 & 1 & 3 \\
Major bacterial infections & 0 & 0 & 0 & 0 \\
Fungal infections & 1 & 5 & 7 & 2 \\
Deaths from infections & 0 & 0 & 0 & 0 \\
\hline
\end{tabular}

In contrast, the incidence of clinical fungal infection (oral and perianal candidiasis) was disturbingly high, especially among those receiving antibiotics $(18 \%)$. Of those not receiving antibiotics, $2 \%$ showed clinical evidence of infection (Table IV).

Four deaths occurred in the series. Three infants with gestational ages by dates of less than 28 weeks died within 24 hours of birth. At necropsy, infection was not thought to be a contributory factor. One infant with gross hydrocephalus, myelomeningocele, and spina bifida died after delivery by destructive craniotomy.

Bacteriological investigations at fourth day. Examination of the fourth-day specimen cultures revealed a very clear contrast between those from the treated groups ( $B$ and $C$ ) and those from the untreated groups (A and D). The most striking effect was a general suppression of growth from all sites in the treated cases along with a notable alteration of the bacterial flora of the faeces.

At 4 days the faeces of infants untreated by antibiotics yielded profuse growths of Esch. coli in $89 \%$ and growths of coliform bacilli or enterococci in a further $9 \%$. No yeasts were isolated from the faeces of any untreated case.

The faeces of infants on antibiotics at 4 days yielded profuse and pure growths of yeasts in $70 \%$ and no growth in a further $17 \%$, small numbers of coliform bacilli being isolated from $13 \%$ of treated infants. These laboratory results correlated with the clinical evidence of candidiasis already referred to.

\section{Discussion}

There is no generally accepted definition of 'premature rupture of the membranes'. Lebherz, Boyce, and Huston (1961) included in their series all cases in which the membranes were ruptured for one hour or more before the onset of regular uterine contractions. Pryles and his colleagues (1963) based their study on those cases where rupture had taken place 6 hours or more before delivery. $\mathrm{Oh}$ et al. (1964) used a somewhat longer period of 18 hours. A more common convention is to regard as premature, rupture of the membranes occurring 24 hours or more before delivery (Wilson et al., 1964). This convention has been used in this study. Gosselin (1937) has shown that within 24 hours of membrane rupture bacterial colonization of the amniotic fluid occurs in $80 \%$ of cases. It must therefore be conceded that the environment of the study cases was at least potentially hazardous to the fetus before delivery. Nevertheless, in the series we have studied, the incidence of significant contamination of the infant immediately after delivery was low (3\%) and in no case was demonstrable bacteriological colonization at birth followed by clinical infection later. This is in keeping with the observation of Blanc (1961) that overt infection is rare in infants known to have been colonized in utero.

Further reason to question the severity of the risk caused to the infant by bacterial invasion of the amniotic fluid is provided by the recent observations of the aetiology of 'congenital pneumonia'. Previously believed to result from the inhalation of infected material, this condition is now thought to be chiefly the result of fetal asphyxia (Davies and Aherne, 1962).

In this series the incidence of neonatal bacterial infection after prolonged rupture of the membranes was low (3\%) and was the same as the incidence after normal delivery. None of the infections occurred in infants who showed bacterial growths at birth. These observations suggest that there is little relation between prolonged rupture of the membranes and neonatal infection. The rationale for the administration of antibiotics is therefore doubtful as it was shown that the incidence of infection in the untreated patients (Group A) did not differ significantly from the incidence in those who were given antibiotics (Groups $B$ and $C$ ).

This study not only failed to confirm the place of routine antibiotic prophylaxis but also illustrated an undesirable effect of their use: $70 \%$ of cases receiving antibiotics excreted fungi in the stools on the fourth day of life, the growth of these antibiotic-resistant yeasts being the sequel of suppression of the normal bowel flora by the broad spectrum antibiotics used. Clinical thrush occurred in $18 \%$ of cases receiving antibiotics. Further, it is probable that the use of prophylactic antibiotics affected adversely the ecology of the neo- 
TABLE IV

Comparison of Fungal Growth in Infants Receiving or Not Receiving Antibiotics

\begin{tabular}{|c|c|c|}
\hline & $\begin{array}{c}\text { Infants } \\
\text { Receiving } \\
\text { Antibiotics }\end{array}$ & $\begin{array}{c}\text { Infants } \\
\text { Not Receiving } \\
\text { Antibiotics }\end{array}$ \\
\hline $\begin{array}{l}\text { No. of infants } \\
\text { Clinical candidiasis } \\
\text { Positive stool culture } \\
\text { (yeasts) on day } 4\end{array}$ & $\begin{array}{l}66 \\
12(18 \%) \\
46(69 \cdot 6 \%)\end{array}$ & $\begin{array}{l}129 \star \\
3(2 \cdot 3 \%) \\
0\end{array}$ \\
\hline
\end{tabular}

*One infant of Group D received antibiotics after aspirationfaeces showed presence of yeasts on day 4 .

natal unit by encouraging the dispersion of fungi. Though there has been no mortality or serious morbidity, fungal infections contribute substantially to the total number of minor infections occurring in the unit, giving an overall incidence of $1.6 \%$ of all infants in the unit.

The bacteriological investigations carried out on the fourth day of this trial indicated a further potential hazard: $45 \%$ of the treated infants had completely negative cultures from all sites, apart from faecal yeasts. This unnaturally 'sterile' state retards normal colonization and may render the infant vulnerable to colonization or infection by antibiotic-resistant pathogens or opportunists which are difficult to treat (Jevons, 1970). Price and Sleigh (1970) have reported an outbreak of Klebsiella aerogenes infection leading to 8 deaths in an intensive care unit, which was attributable to the use of prophylactic antibiotics and was controlled by the withdrawal of antibiotics. The results of this trial indicate that prophylactic administration of antibiotics to infants delivered after prolonged rupture of the membranes is unnecessary and potentially dangerous.

\section{REFERENCES}

Anderson, G. S., Green, C. A., Neligan, G. A., Newell, D. J., and Russell, J. K. (1962). Congenital bacterial pneumonia. Lancet, 2, 585.

Blanc, W. A. (1961). Pathways of fetal and early neonatal infection. fournal of Pediatrics, 59, 473.

Bound, J. P., Butler, N. R., and Spector, W. G. (1956). Classification and causes of perinatal mortality. Part II. Factors in pregnancy and labour influencing perinatal mortality. British Medical fournal, 2, 1191 and 1260.

Davies, P. A., and Aherne, W. (1962). Congenital pneumonia. Archives of Disease in Childhood, 37, 598.

Gosselin, O. (1937). Étude de l'invasion microbienne de l'œuf au cours du travail par la ponction abdominale du liquide amniotique. Bruxelles-Médical, 17, 1600.

Gotoff, S. P., and Behrman, R. E. (1970). Neonatal septicemia. fournal of Pediatrics, 76, 142.

Gould, J. C. (1965). Quantity and quality in the diagnosis of urinary tract infections. British fournal of Urology, 37, 7.

Jevons, M. P. (1970). Use of broad-spectrum antibiotics. British Medical fournal, 2, 540.

Lebherz, T. B., Boyce, C. R., and Huston, J. W. (1961). Premature rupture of the membranes. American fournal of Obstetrics and Gynecology, 81, 658.

Oh, W., Keller, R., Klein, R. I., and Kunstadter, R. H. (1964). Antibiotics in infants for premature rupture of membranes. American Fournal of Diseases of Children, 108, 149.

Petersdorf, R. G., Curtin, J. A., Hoeprich, P. D., Peeler, R. N., and Bennett, I. L., Jr. (1957). A study of antibiotic prophylaxis in unconscious patients. New England fournal of Medicine, 257,1001 .

Price, D. J. E., and Sleigh, J. D. (1970). Control of infection due to Klebsiella aerogenes in a neurosurgical unit by withdrawal of all antibiotics. Lancet, 2, 1213,

Pryles, C. V., Steg, N. L., Nair, S., Gellis, S. S., and Tenney, B. (1963). A controlled study of the influence on the newborn of prolonged premature rupture of the amniotic membranes and/or infection in the mother. Pediatrics, 31, 608.

Urquhart, G. E. D., and Gould, J. C. (1965). Simplified technique for counting the number of bacteria in urine and other fluids. fournal of Clinical Pathology, 18, 480.

Wilson, M. G., Jr., Armstrong, D. H., Nelson, R. C., and Boak, R. A. (1964). Prolonged rupture of fetal membranes. American Fournal of Diseases of Children, 107, 138.

Correspondence to Dr. W. M. McCrae, Department of Child Life and Health, University of Edinburgh, 17 Hatton Place, Edinburgh EH9 1UW. 